\section{Ongelmia työssä ja toimeentulossa vai sittenkin järjestelmissä?}

Suoranta, Anu \& Leinikki, Sikke (toim.) (2018) Rapautuvan palkkatyön yhteiskunta. Mikä on työn ja toimeentulon tulevaisuus? Vastapaino. 178 sivua.

TEOKSEN ERITYISNÄKÖKULMANA on "muu kuin vakituinen ja kokoaikainen palkkatyö", kuten teoksen toimittajat haluavat tätä toimeentulon muotoa nimittää.

Aikana, jona niin tutkimusideoiden kuin startuppienkin kohtalo ratkaistaan hissipuheiden perusteella, kirja on äänestettävä ehdottomasti jatkoon. Nimittäin heti sisällysluettelosta käy ilmi kunkin luvun ja kirjoittajan pääsanoma, eivätkä toimittajat pitkitä kirjan vauhtiin pääsyä kuivalla lukujen kuvauksella.

Artikkelipohjaisen teoksen kirjoittajista jotkut työskentelevä tutkijoina, mutta useimmat saavat palkkansa tutkimusmaailman ulkopuolelta, kuten ammattiyhdistysliikkeestä, Kelasta tai Telasta. Kirjoittajien taustat toki näkyvät tekstien painotuksissa, mutta kokonaisuudessaan teos on yllättävänkin tasapainoinen luettava. Sitä vo suositella jokaiselle palkkatyösuhteiden ja niiden varaan rakentuvan yhteiskuntajärjestelmän historiasta, kipupisteistä ja tulevaisuudesta kiinnostuneelle. Aiempaa ymmärrystä aihepiiristä ei välttämättä vaadita, mutta haittaakaan siitä ei ole.

En käy kirjaa läpi luku luvulta, vaan nostan esiin puhtaasti subjektiiviseen mielipiteeseeni pohjaten muutamia makupaloja.

\section{TUORE NÄKÖKULMA}

MAAPALLON KANTOKYVYSTÄ

Kolmas luku voittaa tuoreen näkökulman palkinnon. Olen kahlannut läpi tuhansia sivuja tekstejä työn tulevaisuudesta, katoavista ammateista ja uusista työn teon käytännöistä. En usko aiemmin nähneeni nousevien ammattien listalla metsuria ja maanviljelijää. Tämä johtuu siitä, että arviolta 95 prosenttia työelämän tulevaisuuden tutkimuksista perustuu teknologiaennakointiin, vaikka muitakin vaihtoehtoja olisi.

Tutkijat Paavo Järvensivu ja Tero Toivanen ovat löytäneet vaihtoehdon. He seuraavat suomalaisen työelämän tutkimuksen grand old manin Antti Kasvion viitoittamaa polkua ottaen perustakseen maapallon asettamat rajat. He tarttuvat ilmastonmuutoksen teemaan analysoiden, mitä tämän ihmiskunnan kohtalonkysymyksen vakavasti ottaminen tarkoittaisi työn näkökulmasta.

Järvensivu ja Toivanen puhuvat ekologisen jälleenrakennuksen ajasta, jolloin ihmiset jälleen työllistävät itsensä rakentamal la talonsa puusta, ompelemalla vaatteensa laadukkaiksi, käyttämällä aikaa lastensa kasvatukseen, kääntämällä kasvimaansa lapiolla ja kaatamalla puunsa sahalla. $\mathrm{He}$

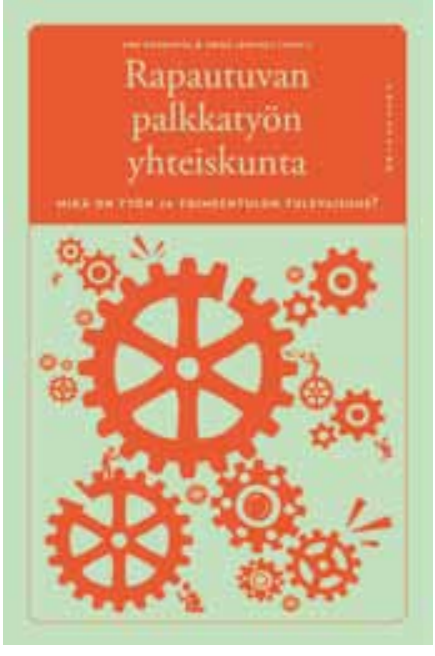

outuvat kuitenkin toteamaan että nykyinen tulopolitiikka ja palkkaus eivät juuri palkitse kestävää yhteistä tulevaisuutta rakentavista töistä, vaan ennemmin yhteiskunta palkitsee edelleen fossiilitaloutta tukeneiden työnjaon, sukupuolijärjestelmän ja altasuhteiden mukaisesti

Teema on niin merkittävä ja laja, että siinä riittää vielä tutkioille paljon pureksittavaa. Eivätkà tutkijat suinkaan ole ainoa työelämäkentän toimijaryhmä, jonk ekologinen herääminen voisi johtaa yllättävien työn tulevaisuuskuvien syntymiseen. Näemmekö kenties ajan, jolloin lentomatkusminen on niin suuri häpeä, ettra ammattiyhdistysliike puolusta työtä tekevien oikeutta jättää työmatkat lentämättä?

\section{ÄYTTÖKELPOISTEN}

KÄSITTEIDEN PARAATI

Luvun kuusi kirjoittanut Kelan johtava tutkija Pertti Honkanen

OLISIKO PAREMPI SIIRTY $\ddot{A}$ UUTEEN JÄRJESTELMÄ̈̈N

KUIN TILKITÄ IKUISESTI VANHAA?

ansaitsee kunniamaininnan käyttökelpoisten käsitteiden läpikäynnistä ja reflektiivisestä tilastojen esittelystä. Hän luettelee numeroita ja kuvaa niiden avulla muutoskulkuja. Samalla hän kuitenkin tuo reilusti esiin, miten puutteellinen tilastojen tuottama kuva on etenkin silloin, kun yritetään tavoittaa uusien ilmiöiden kehkeytymistä j ihmisten todellisuuksien moninaisuutta. Jopa "rajallinen tilastotieto" silti kertoo, että Suomessa työttömyys on kasvanut vuosikymmenestä toiseen, osa-aikatyö on yleistynyt ja yrittäjyys lisääntynyt ja polarisoitunut. Tekstinsä lopuss Honkanen kysyy rohkeasti, olisiko parempi siirtyä uuteen järjestelmään kuin tilkitä ikuisesti vanha. Kysymys on perusteltu, mutta ei selvästikään edusta kaikkien kirjaan kirjoittaneiden ajattelua.

\section{KIINNOSTAVIA PALJASTUKSIA}

Luvut seitsemän ja yhdeksän jakavat kiinnostavimpien paljastusten palkinnon. Kansanedustaja (vihr.) Outi Alanko-Kahiluoto käy läp eduskuntakeskusteluja vuosilt 2007-2017. Kirjoitus paljastaa, miten vaikea asia itsensätyöllistäjyyden lisääntyminen on nimenomaan suomalaiselle yhteiskuntajärjestelmälle, jonka rakenteiden ja intressijärjestelmien puristuksess käydään vuosikymmeniä kestänytta kroonistunutta keskustelua itsensätyöllistäjän turvasta sekä tarpeesta rakentaa lainsäädäntöön niin sanottu kolmas kategoria palkansaajan ja yrittäjän oheen.

Samasta hitaasta kiirehtimisestä todistaa toimihenkilöliitto ERTOn puheenjohtaja Juri Aaltonen kertoessaan omakohtaisen tarinansa Euroopan unionin työaikadirektiivin kehittämisprosessista. Tapauskuvauksessa työsuhteen sisään rajautuva työntekijän suojelu ei enää jaksanut kiinnostaa Aaltosen etelämpää tulleita kollegoja, sillä he ajattelivat itsensätyöllistäjyyden ja muiden uudenlaisten yrittäjyyksien lisääntymisen siinä määrin itsestään selväksi muutoskuluksi.

Näiden kahden luvun valossa onkin mielenkiintoista nähdä, jatkuuko suomalainen maltillisten muutosten tarina vai syntyykö esimerkiksi eduskunnan tulevaisuusvaliokunnan tuoreessa julkaisussa esitetyn työlainsäädännön ja toimeentuloturvan kokonaisuudistuksen, eli "toimeentulokaaren" pohjalta jotain oikeasti uutta.

\section{ITSENSÄTYÖLLISTÄJÄN OMA} ÄÄNI PUUTTUU

Mietin pitkään, miksi minulle jäi kirjasta vaivautunut olo. Kirjahan on mielenkiintoinen, monipuolinen, monitasoinen ja selkeä. Se käsittelee ehdottoman tärkeää ja ajankohtaista tematiikkaa. Se kannattaa lukea kokonaan. Opin kirjasta paljon, ja olen useita kertoja viitannut siihen omissa teksteissäni. Mikäli onnistun työllistämään itseäni työelämäasioiden tuntijana jatkossakin, aion vielä monta kertaa viitata kirjan lukuihin.

Kirjasta uupuu kuitenkin jotain hyvin tärkeää, ja se minua jäi vaivaamaan. Vaikka kirja on ajateltavissa itsensätyöllistäjien tai muussa kuin vakituisessa kokoaikaisessa palkkatyössä työllistyvien puolustukseksi, se on kirja toisista. Siinä puhutaan yli niiden äänen, joiden puolelle asettaudutaan.

Ehkä kirja onkin ajateltavissa sarjan ensimmäiseksi osaksi. Ihannetulevaisuudessa ilmestyisi sarjan toinen osa, jossa kertojina olisivat ansaintansa erilaisista toimeentulonmuodoista koostavat, siis ihmiset itse. Siinä näihin työmarkkina-asemiin syystä tai toisesta lyhemmäks tai pidemmäksi ajaksi päätyneet ihmiset kuvaisivat arkensa, sen ilot ja surut. He itse ilmoittaisivat, mikä on heille hyvää ja miten he haluavat tulla turvatuiksi ja puolustetuiksi. Vasta sen kirjan jälkeen kuva itsensätyöllistäjyydestä ja itseään työllistävistä olisi täydellinen.

ANU JÄRVENSIVU

FT, dosentti

yväskylän yliopisto Tampereen yliopisto 